\title{
AKIBAT HUKUM PERJANJIAN KAWIN TERHADAP PIHAK KETIGA DALAM PERSPEKTIF PUTUSAN MAHKAMAH KONSTITUSI NO. 69/PUU-XIII/ 2015
}

\author{
Putu Trisna Witariyani, I Nyoman Sujana, Ni Made Puspasutari Ujianti \\ Fakultas Hukum Universitas Warmadewa, Denpasar-Bali, Indonesia
}

\begin{abstract}
Abstrak
Masalah harta kekayaan dalam perkawinan sering terjadi. Dengan itu pasangan dapat membuat perjanjian kawin bagi yang ingin memisahkan harta perkawinan mereka. Salah satu pengaturan perjanjian kawin yaitu disebutkan dalam ayat (1) yaitu dalam Pasal 29 Undang - Undang Nomor 1 Tahun 1974 tentang perkawinan menyebutkan bahwa perjanjian kawin dapat dibuat sebelum perkawinan berlangsung dan mengikat pihak ketiga selama pihak ketiga tersangkut. Tapi, setelah keluarnya Putusan Mahkamah Konstitusi No. 69/PUU-XIII/2015 pengaturan perjanjian dalam perkawinan berubah. Penelitian ini bertujuan untuk mengetahui pengaturan perjanjian kawin sesudah adanya Putusan Mahkamah Konstitusi No. 69/PUU-XIII/2015 dan mengetahui akibat hukum terhadap pihak ketiga dengan adanya perjanjian kawin sesudah keluarnya Putusan Mahkamah Konstitusi No. 69/PUUXIII/2015. Metode penelitian yang digunakan yaitu metode penelitian Normatif dimana pengkajiannya didasarkan atas bahan-bahan hukum dari literatur yang ada. Hasil analisis menunjukan bahwa pengaturan perjanjian kawin berubah semenjak adanya Putusan Mahkamah Konstitusi tersebut dimana perubahannya yaitu bahwa perjanjian kawin dapat dibuat sebelum atau sesudah perkawinan, berlaku sesudah perkawinan kecuali para pihak menentukan lain, dan juga perjanjian kawin dapat dirubah dan dicabut sesuai dengan persetujuan suami dan istri. Jika perjanjian dalam perkawina tersebut didaftarkan maka perjanjian tersebut akan diberlakukan bagi pihak ketiga. Bagi pasangan yang ingin membuat perjanjian kawin seharusnya mengikuti aturan yang ada agar perjanjian kawin tersebut sah dan tidak merugikan pihak ketiga.
\end{abstract}

Kata Kunci: Perjanjian Kawin, Pihak Ketiga, Akibat Hukum

\begin{abstract}
Property problems in marriage often occur. With this, the couple can make a marriage agreement for those who want to separate their marital assets. One of the marriage agreement arrangements, which is mentioned in paragraph (1), namely in Article 29 of Law Number 1 of 1974 concerning marriage states that a marriage agreement can be made before the marriage takes place and binds a third party as long as the third party is involved. However, after the issuance of the Constitutional Court Decision No. 69 / PUU-XIII / 2015 the arrangement of the agreement in marriage has changed. This study aims to determine the arrangement of the marriage agreement after the Constitutional Court Decision No. 69 / PUU-XIII / 2015 and knowing the legal consequences for third parties with the existence of a marriage agreement after the issuance of the Constitutional Court Decision No. 69 / PUU-XIII / 2015. The research method used is the Normative research method where the assessment is based on legal materials from the existing literature. The results of the analysis show that the marriage agreement arrangements have changed since the Constitutional Court Decision, where the amendment is that the marriage agreement can be made before or after marriage, applies after marriage unless the parties determine otherwise, and also the marriage agreement can be changed and revoked according to the agreement of the husband and wife. If the agreement in marriage is registered, the agreement will be enforced for the third party. Couples who want to make a marriage agreement should follow the existing rules so that the marriage agreement is valid and does not harm third parties.
\end{abstract}

Keywords: Marriage Agreement, Third Party, Legal Consequences

\section{PENDAHULUAN}

Hak dan Kewajiban pasangan dalam perkawinan ini ditimbulkan karena perkawinan adalah perbuatan hukum yang menghasilkan akibat hukum (Hartanto, 2010). Namun, bagi pasangan yang akan melangsungkan perkawinan kemungkinan besar perkawinan tersebut akan menimbulkan sebuah masalah tentang harta kekayaan yaitu mengenai harta benda pribadi atau harta bawaan dan juga mengenai harta bersama suami dan istri. 
Suatu perkawinan dilangsungkan karena adanya rasa saling percaya satu dengan yang lain maka kebanyakan orang yang akan melangsungkan perkawinan, mereka pada umumnya tidak mempeributkan masalah percampuran harta kekayaan perkawinan. Beberapa penelitian berikut ini membahas tentang perkawinan/pernikahan seperti Chen \& van Ours (2020); Dwinopianti (2017); Efevbera \& Farmer (2019); Kenny, Koshin, Sulaiman, \& Cislaghi (2019); Kern (2010); Kiconco \& Nthakomwa (2018); Minten \& Dykeman (2020). Perlahan pemikiran masyarakat mulai berubah, para pasangan yang akan melangsungkan perkawinan mulai mempermasalahkan harta kekayaan dalam perkawinan mereka dikarenakan adanya perkembangan jaman dan pengaruh budaya asing.

Dikarenakan pasangan perkawinan pada saat ini banyak yang sudah bekerja dan juga sudah bisa menghasilkan harta sendiri, jadi pada saat ini banyak pasangan yang mempermasalahkan mengenai harta masing-masing atau harta bawaan sebelum terjadinya suatu perkawinan sehingga banyak pasangan yang berpendapat bahwa dalam perkawinan mereka perlu membuat dan mengatur perjanjian dalam perkawinan. Undang-Undang telah mengatur peraturan bagi calon suami dan calon istri yang ingin dalam perkawinannya tidak terjadi penggabungan harta, yaitu dengan membuat Perjanjian kawin (Hartanto, 2010).

Perjanjian Kawin (huwelijks atau huwelijkse voorwaarden) adalah suatu perjanjian yang dimana dibuat oleh calon pasangan yang akan menikah dengan tujuan mengatur harta kekayaan mereka setelah mereka menikah (Prawirohamidjojo, 2000). Perjanjian dalam perkawinan terdapat dalam UU Perkawinan, salah satunya yaitu dalam Pasal 29 ayat (1) yang menyatakan perjanjian dalam perkawinan dibuat sebelum pasangan melangsungkan perkawinan dan jika ingin perjanjian kawin tersebut mengikat pihak ketiga maka perjanjian tersebut harus dicatat oleh pegawai pencatat perkawinan.

Namun, perjanjian dalam perkawinan terjadi pembaharuan setelah keluarnya Putusan Mahkamah Konstitusi Nomor 69/PUU-XIII/2015. Putusan Mahkamah Konstitusi tersebut dikeluarkan karena adanya permohonan pengajuan uji materiil atau judicial review yang dilakukan oleh Nyonya Ike Farida terhadap Pasal 29 ayat (1), ayat (3), ayat (4) dan Pasal 35 ayat (1) yang terdapat dalam UU Perkawinan terhadap UUD 1945.

Salah satu perubahan yang dilakukan oleh Mahkamah Konstitusi yaitu terhadap Pasal 29 ayat (1) UU Perkawinan dimana perubahannya yaitu: pembuatan perjanjian perkawinan dapat dilakukan sebelum perkawinan atau sesudah perkawinan dan perjanjian itu disahkan oleh pegawai pencatat perkawinan atau Notaris, dan diberlakukan kepada pihak ketiga jika perjanjian kawin terikat oleh pihak ketiga. Jadi, perjanjian dalam perkawinan itu dapat dibuat sesudah berlangsungnya perkawinan. Hal inilah yang dapat menimbulkan kerugian bagi pihak ketiga, mengingat pihak ketiga tidak pernah tahu akan perubahan sumber-sumber harta yang dituangkan dalam perjanjian kawin setelah perkawinan berlangsung. Berdasarkan latar belakang diatas, penelitian ini bertujuan untuk mengetahui pengaturan perjanjian kawin sesudah adanya Putusan Mahkamah Konstitusi No. 69/PUU-XIII/2015 dan mengetahui akibat hukum terhadap pihak ketiga dengan adanya perjanjian kawin sesudah keluarnya Putusan Mahkamah Konstitusi No. 69/PUU-XIII/2015.

\section{METODE PENELITIAN}

Penelitian ini menggunakan metode penelitian hukum normatif dengan menggunakan penndekatan masalah yaitu pendekatan perundang-undangan dan pendekatan konseptual. Pendekatan perundangundangan adalah suatu pendekatan dimana suatu peraturan perundang-undangan ditelaah dengan baik dan peraturan perundang -undangan tersebut juga berhubungan dengan permasalahan yang ada. Sedangkan pendekatan konseptual merupakan suatu pendekatan yang di dalam ilmu hukum ada dan berkembang pemikiran dan doktrin para sarjana.

Adapun sumber bahan hukum yang digunakan berupa 1) bahan hukum primer yaitu bahan-bahan hukum berupa peraturan perundang-undangan yakni: KUHPERdata, Undang-Undang Nomor 1 Tahun 1974 tentang Perkawinan, Undang-Undang No. 2 Tahun 2014 tentang perubahan atas UndangUndang No. 30 tahun 2004 tentang Jabatan Notaris, Putusan Mahkamah Konstitusi No. 69/PUUXIII/2015 Tentang Pengujian Undang-Undang Nomor 5 tahun 1960 tentang Peraturan Dasar PokokPokok Agraria dan Undang-Undang Nomor 1 tahun 1974 tentang Perkawinan terhadap UUD 1945 dan 2) bahan hukum sekunder yaitu bahan-bahan hukum yang diperoleh dari pengkajian kepustakaan (Library research) yaitu dengan membaca buku-buku hukum, jurnal-jurnal hukum, surat kabar dan 
juga dari internet yang berkaitan dengan perjanjian kawin pasca Putusan Mahkamah Konstitusi No.69/PUU-XIII/2015.

Teknik pengumpulan bahan hukum dengan melakukan pencatatan bahan hukum primer dan bahan hukum sekunder serta dengan cara membaca buku-buku, peraturan perundang-undangan serta literatur lainnya yang ada kaitannya dengan permasalahan dari penulis bahas tentang perjanjian dalam perkawinan setelah keluarnya Putusan Mahkamah Kosntitusi No. 69/PUU-XIII/2015.

\section{HASIL DAN PEMBAHASAN}

\section{Pengaturan Perjanjian Kawin di Indonesia Sesudah Adanya Putusan Mahkamah Konstitusi} No.69/PUU-XIII/2015

Pengaturan mengenai perjanjian dalam perkawinan berubah setelah adanya Putusan MK No. 69/PUUXIII/2015. Putusan itu menguji Undang-Undang Agraria dan juga Undang-Undang Perkawinan. Dimana putusan ini menimbulkan pembaharuan terhadap pengaturan perjanjian kawin, yaitu : UU Perkawinan Pasal 29 ayat (1) menyebutkan dalam pembuatan perjanjian dalam perkawinan dilakukan sebelum pasangan menikah, jika ingin perjanjian kawin tersebut mengikat pihak ketiga maka perjanjian tersebut harus dicatat oleh pegawai pencatat perkawinan. Sedangkan adanya pembaharuan dari Putusan menjadi suami istri bisa melakukan pembuatan perjanjian kawin sebelum atau sesudah perkawinan berlangsung dan jika ingin perjanjian kawin tersebut mengikat pihak ketiga maka perjanjian tersebut harus disahkan oleh pegawai pencatat perkawinan atau disahkan Notaris.

UU Perkawinan Pasal 29 ayat (3) menyebutkan perjanjian dalam perkawinan berlaku bagi para pihak sejak pasangan sudah menikah. Sedangkan sesudah keluarnya Putusan ini berubah menjadi perjanjian kawin berlaku bagi para pihak sejak pasangan sudah menikah kecuali perjanjian kawin tersebut menentukan kapan keberlakuan perjanjian tersebut.

UU Perkawinan Pasal 29 ayat (4) menyebutkan bahwa perjanjian dalam perkawinan tidak diijinkan dirubah pada saat perkawinan kecuali ada persetujuan dari suami istri yang membuat perjanjian tersebut untuk mengubahnya dan perubahan tersebut tidak merugikan pihak ketiga. Sedangkan, setelah keluarnya Putusan berubah menjadi: Pasangan suami istri tersebut tidak diijinkan untuk merubah atau mencabut kecuali ada persetujuan dari kedua pihak yang membuatnya dan tentunya pihak ketiga tidak dirugikan atas perubahan atau pencabutan tersebut.

\section{Akibat Hukum Pembuatan Perjanjian Kawin Sesudah Adanya Putusan Mahkamah Konstitusi No.69/PUU-XIII/2015 terhadap Pihak Ketiga}

Perjanjian kawin selain mengikat para pembuatnya yaitu pasangan suami dan istri, perjanjian dalam perkawinan juga dapat mengikat pihak ketiga. Pihak ketiga dalam pembuatan perjanjian kawin biasanya seorang Kreditur yang dimana suami atau istri tersebut memiliki hutang kepada kreditur tersebut. Pembuatan perjanjian kawin berhubungan dengan kreditur ini karena pelunasan dari hutang ini berhubungan dengan harta kekayaan yang dimiliki suami dan istri tersebut. Ketentuan mengenai perjanjian kawin mengikat pihak ketiga disini diatur dalam Pasal 152 KUHPerdata dimana ketentuan ini menyebutkan jika pihak ketiga tidak akan tersangkut perjanjian dalam perkawinan jika perjanjian dalam perkawinan tersebut tidak terdaftar dalam daftar umum di kepaniteraan pada Pengadilan Negeri dimana perkawinan tersebut dilaksanakan atau jika perkawinan tersebut dilaksanakan diluar negeri maka perjanjian tersebut didaftarkan ditempat akta perkawinan didaftarkan. Dilihat dari ketentuan dalam Pasal 152 KUHPerdata tersebut bahwa perjanjian kawin juga bisa mengikat pihak ketiga jika perjanjian dalam perkawinan tersebut di daftarkan di Kepaniteraan Pengadilan Negeri.

Dilihat dari pengaturan dalam KUHPerdata tersebut bahwa suatu perjanjian kawin dibuat sebelum perkawinan berlangsung dan akan mengikat pihak ketiga jika perjanjian tersebut didaftarkan terlebih dahulu dan juga mengikat bagi pihak ketiga sesudah perkawinan itu didaftarkan di tempat yang sudah ditentukan oleh undang-undang. Jika pihak ketiga mengetahui ada perjanjian dalam perkawinan yang tidak terdaftar, maka perjanjian dalam perkawinan itu tidak berlaku untuk pihak ketiga dan juga Ia (pihak ketiga) boleh menganggap bahwa tidak ada perjanjian kawin, demikian pemikiran Hoge Raad sesuai Arrestnya tertanggal 18 april 1947 dan 29 april 1949 (Prawirohamidjojo, 2000). Jika perjanjian dalam perkawinan sudah terdaftar dan pihak ketiga (kreditur) sudah mengetahui adanya perjanjian kawin tersebut maka kreditur dapat menagih pelunasan hutang dengan pihak yang mempunyai hutang tersebut yaitu suami atau istri. 
Dalam Putusan MK yang mengubah Pasal 29 ayat (1) UUP menyebutkan bahwa pembuatan perjanjian perkawinan dapat dilakukan sebelum atau sesudah perkawinan berlangsung dan perjanjian itu disahkan oleh pegawai pencatat perkawinan atau disahkan Notaris. Kerena Notaris yang membuat Akta Perjanjian Perkawinan tersebut maka Notaris sangat diperlukan dalam membuat suatu perjanjian kawin. Jika perjanjian kawin dibuat dengan akta Notaris maka perjanjian kawin tersebut tidak akan merugikan pihak-pihak yang bersangkutan karena Notaris memiliki kewajiban seperti yang disebutkan dalam Undang-Undang No. 2 Tahun 2014 Perubahan Undang-Undang No. 30 Tahun 2004 tentang Jabatan Notaris atau yang biasa disebut UUJNP yaitu Pasal 16 ayat (1) huruf a menyatakan saat menjalankan jabatannya Notaris wajib bertindak jujur, tidak berpihak dan menjaga kepentingan pihak.

Bagi Notaris, tidak mudah menerima pembuatan akta perjanjian kawin yang tidak merugikan pihak ketiga. Tapi, Notaris dapat melakukan antisipasi agar pihak ketiga tidak dirugikan oleh adanya perjanjian kawin yaitu Notaris dapat mempertanyakan dan memastikan mengenai harta kekayaan dan status harta tersebut apakah harta tersebut dijadikan jaminan kepada pihak ketiga, jika sudah diketahui Notaris dapat meminta persetujuan pihak ketiga mengenai harta yang dijadikan jaminan tersebut diperjanjikan dalam perjanjian kawin.

Lalu bagaimana jika suami istri membuat perjanjian perkawinan dan Notaris tidak melakukan antisipasi tersebut dan perjanjian tersebut ternyata merugikan pihak ketiga? Jika pihak ketiga atau dalam hal ini kreditur merasa dirugikan dengan adanya perjnjian kawin yang dibuat oleh pasangan suami istri sesudah pernikahan, maka kreditur dapat melakukan gugatan ke pengadilan untuk membatalkan perjanjian tersebut jika gugatan tersebut dikabulkan oleh hakimdan gugatan ini atas dasar asas Actio Pauliana. Actio Pauliana yang diatur dalam Pasal 1341 KUHPERdata yang menyebutkan bahwa kreditur dapat mengajukan tidak berlakunya segala tindakan yang dilakukan debitur yang dapat merugikan kreditur asal ada bukti bahwa tindakan tersebut merugikan kreditur.

\section{SIMPULAN DAN SARAN}

\section{Simpulan}

Pengaturan perjanjian kawin mengalami perubahan yang signifikan setelah adanya Putusan MK yaitu terhadap Pasal 29 ayat (1), ayat (3) dan Ayat (4) UUP perubahan itu seperti perjanjian kawin dapat dibuat sesudah perkawinan berlangsung, berlakunya perjanjian kawin dapat ditentukan lain di dalam perjanjian bukan hanya diberlakukan setelah perkawinan, dan juga perjanjian kawin dapat diubah dan dicabut jika ada persetujuan dari para pihak. Jika perjanjian kawin didaftarkan dan pihak ketiga tahu akan adanya perjanjian kawin tersebut dan juga tidak merugikan pihak ketiga maka perjanjian tersebut mengikat pihak ketiga, jadi jika suami istri memiliki hutang dengan pihak ketiga maka pembayarannya menyesuaikan dengan perjanjian kawin tersebut. Sedangkan jika sudah didaftarkan tetapi pihak ketiga tidak tahu maka pihak ketiga dapat melakukan perbuatan dengan menagih hutang suami istri menggunakan kekayaan bersama. Sedangkan jika perjanjian kawin sudah didaftarkan tapi merugikan pihak ketiga maka pihak ketiga dapat mengajukan gugatan ke pengadilan untuk membatalkan perjanjian tersebut yang berasaskan Actio Pauliana.

\section{Saran}

Melalui penelitian ini diharapkan kepada calon suami istri dan yang sudah sah menjadi suami istri untuk membuat perjanjian kawin dan mengikuti peraturan yang ada mengenai perjanjian kawin agar perjanjian tersebut sah dan mengikat pihak ketiga jika pihak ketiga tersangkut. Selanjutnya, kepada Notaris yang akan membuat Akta perjanjian kawin, sebaiknya, lebih berhati-hati dalam melayani pembuatan perjanjian kawin sesuai dengan peraturan dan ketentuan ketentuan yang ada dan juga memperhatikan larangan-larangan dalam pembuatan perjanjian kawin. Kemudian, kepada kreditur untuk lebih memperhatikan dan memastikan jika ada debitur yang memiliki hutang tersebut memiliki perjanjian kawin atau tidak.

\section{DAFTAR PUSTAKA}

Chen, S., \& van Ours, J. C. (2020). Symbolism Matters: The effect of Same-Sex Marriage Legalization on Partnership Stability. Journal of Economic Behavior and Organization, 178, 44-58.

Dwinopianti, E. (2017). Implikasi dan Akibat Hukum Putusan Mahkamah Konstitusi Nomor 69/Puu-Xiii/2015 
terhadap Pembuatan Akta Perjanjian Perkawinan Setelah Kawin yang Dibuat di Hadapan Notaris. Jurnal Lex Renaissance, 2(1), 16-34.

Efevbera, Y., \& Farmer, P. (2019). 'It is this which is Normal' A Qualitative Study on Girl Child Marriage and Health in Conakry, Guinea. Journal of Adolescent Health, 64(2), 1-9.

Hartanto, A. (2010). Hukum Harta Kekayaan Perkawinan (Menurut Burgerlijk Wetboek dan Undang-Undang Perkawinan). Yogyakarta: Laksbang Grafika.

Kenny, L., Koshin, H., Sulaiman, M., \& Cislaghi, B. (2019). Adolescent-led Marriage in Somaliland and Putland: A Surprising Interaction of Agency and Social Norms. Journal of Adolescence, 72(January), 101-111.

Kern, H. L. (2010). The political Consequences of Transitions out of Marriage in Great Britain. Electoral Studies, 29(2), 249-258.

Kiconco, A., \& Nthakomwa, M. (2018). Marriage for the 'New Woman' from the Lord's Resistance Army: Experiences of Female Ex-abductees in Acholi Region of Uganda. Women's Studies International Forum, 68(July 2017), 65-74.

Minten, M. J., \& Dykeman, C. (2020). The Impact of a Marriage Checkup with Transgender Couples. Sexologies, $1-7$.

Prawirohamidjojo, S. (2000). Hukum Orang dan Keluarga. Surabaya: Airlangga University Press.

Kitab Undang - Undang Hukum Perdata (KUHPerdata)

Putusan Mahkamah Konstitusi No. 69/PUU-XIII/2015 Tentang Pengujian Undang-Undang Nomor 5 tahun 1960 tentang Peraturan Dasar Pokok - Pokok Agraria dan Undang - Undang Nomor 1 tahun 1974 tentang Perkawinan terhadap UUD 1945.

Undang - Undang Nomor 1 Tahun 1974 tentang Perkawinan

Undang - Undang Nomor 2 Tahun 2014 perubahan atas Undang - Undang Nomor 30 Tahun 2004 tentang Jabatan Notaris 